Terbit online pada laman web jurnal: http://jurnal.iaii.or.id

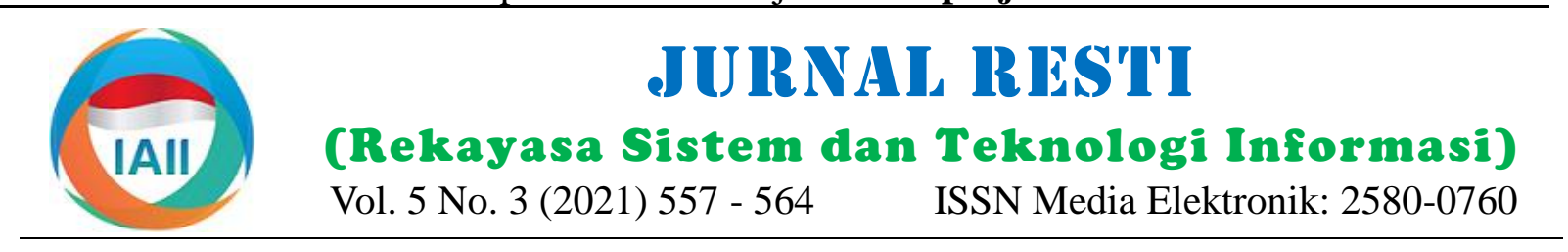

\title{
Perbandingan Metode KNN Dan LBPH Pada Klasifikasi Daun Herbal
}

\author{
Isman $^{1}$, Andani Ahmad ${ }^{2}$, Abdul Latief ${ }^{3}$ \\ ${ }^{1}$ Program Studi Sistem Komputer, Stmik Bina Bangsa Kendari \\ ${ }^{2}$ Program Studi Teknik Elektro, Universitas Hasanudin \\ ${ }^{3}$ Program Studi Sistem Komputer, Stmik Handayani Makassar \\ 1isman@student.handayani.ac.id, 22andani@unhas.ac.id, ${ }^{3}$ latiefarda@gmail.com
}

\begin{abstract}
Herbal plants are plants that can be used as alternatives in natural healing of diseases, parts of plants that can be used such as roots, stems, tubers and leaves, in Southeast Sulawesi there are currently 1000 herbal plants and 10 sub-ethnicities that have been inventoried, according to research conducted by the Ministry of Health (Kemenkes). Indonesia has 6,000 - 7,000 medicinal plants, Southeast Sulawesi Province has a variety of herbal plants that are not found in other areas, such as Komba - Komba or Balakacida (Chromolaena Odorata). However, in the present era, the number of herbal plants is not accompanied by the knowledge of the community about the herbal plants themselves. The purpose of this study is to classify herbal plants and to compare the performance results of the K-Nearest Neighbor Method and Local Binary Pattern Histogram. From the test results of five types of herbal leaves in Southeast Sulawesi with a total of 100 data sets, the accuracy value for the $K$ Nearest Neighbor (KNN) method is obtained total accuracy value is 97,5\%, while for the Local Binary Pattern Histogram (LBPH) method the total value is $94 \%$ of total accuracy value.
\end{abstract}

Keywords: K-Nearest Neighbour, LBPH, Herbal Leaves Sultra

\begin{abstract}
Abstrak
Tanaman Herbal merupakan Tanaman yang dapat dimanfaatkan sebagai pengganti dalam Penyembuhan Penyakit secara Alami, bagian Tanaman yang dapat di gunakan bisa berupa Akar, Batang, Umbi dan Daun, di Sulawesi Tenggara saat ini terdapat 1000 Tanaman Herbal dan 10 Sub Etnik yang telah di Inventarisasi, menurut data Riset yang di Lakukan Oleh Kementrian Kesehatan (Kemenkes). Indonesia memiliki 6.000 - 7.000 Tanaman Obat. Provinsi Sulawesi Tenggara memiliki Beragam Tumbuhan Herbal yang tidak di temukan di daerah lain Seperti Komba - Komba atau Balakcida (Chromolaena Odorata). Namun pada Zaman Sekarang banyaknya Tumbuhan Herbal tidak di barengi dengan Pengetahuan Masyarakat tentang tanaman Herbal itu Sendiri. Tujuan dari Penelitian ini adalah Mengklasifikasikan Tanaman Herbal dan Perbandingan hasil Kinerja Metode K-Nearest Neighbour dan Local Binary Pattern Histogram. Dari hasil pengujian lima Jenis daun Herbal Sulawesi Tenggara dengan total 100 Data Set di dapatkan Nilai Akurasi untuk Metode K-Nearest Neighbour (KNN) di dapatkan nilai Total akurasi sebesar 97,5\%, sedangkan untuk Metode Local Binary Pattern Histogram (LBPH) di dapatkan Total Nilai Akurasi sebesar $94 \%$.
\end{abstract}

Kata Kunci: K-Nearest Neighbour, LBPH, Daun Herbal Sultra

\section{Pendahuluan}

Semenjak dulu Penyembuhan Tradisional sudah di kenali oleh Warga Sulawesi Tenggara di tandai dengan kerutinan para orang tua giat memakai obat tradisonal yang bahannya dari tumbu- tumbuhan yang di ambil dari pekarangan rumah ataupun dekat hutan. Bersamaan dengan pertumbuhan jaman kebiasan tersebut mulai ditinggalkan sehingga warga tergantung pada obat obatan kimia pada pengobatan penyakit [1].
Disulawesi Tenggara sendiri terdapat 1000 Tanaman Herbal dan Sub Etnik yang telah mampu di Inventarisasi Oleh Prof. Dr. I Sahidin dan Timnya, dalam Riset mereka yang telah dilakukan \pm 10 tahun[2]. Sulawesi Tenggara mempunyai bermacam- macam Tanaman Herbal yang tidak dapat ditemui di sebagian Wilayah lain, semacam Tanaman Komba- Komba ataupun Balakacida yang memiliki nama latin Calerodendrum Speciossimum. Tanaman ini sudah dimanfaatkan oleh penduduk semenjak jaman kerajaan Kesultanan Buton [1]. Banyaknya jumlah tanaman obat herbal serta 
minimnya pengetahuan dan Data Warga mengenai jenis Histogram dalam Mengklasifikasikan Daun Herbal di serta tanaman obat herbal yang bisa di manfaatkan Sulawesi Tenggara. Dalam proses pengenalan Daun selaku Obat Akternatif membuat warga jadi kesusahan penulis menggunakan Ekstraksi Tekstur dan Ektraksi dalam perihal membedakan tipe tanaman obat herbal Fitur untuk mendapatkan hasil citra yang ideal.

tersebut, sehingga disaat ini banyak warga yang lebih

tergantung pada pemakaian obat- obatan kimia. Buat 2. Metode Penelitian

membagikan data kepada warga, diperlukan sistem

pengenalan tanaman obat herbal yang dapat menerapkan Proses Klasifikasi dalam penelitian ini menggunakan identifikasi serta pengenalan tanaman obat herbal. Metode K-Nearest Neighbor (KNN) dan Local Binary Informasi yang didapat bisa berbentuk citra digital yang Pattern Histogram untuk mengidentifikasi jenis daun setelah itu dianalisis serta diproses oleh sistem. Sistem Herbal. Ada 5 (Lima) Jenis Daun Herbal Sulawesi mengenali citra daun dari tanaman obat herbal serta Tenggara yang di gunakan yaitu Daun Balakacida mengaplikasikan pengenalan sesuatu pola ataupun ciri (Chromolaena Odarata), Daun Sirih (Piper Betle), dari objek tersebut [3]

Proses klasifikasi tanaman bisa di jalani dengan metode Daun Pepaya (Carica Papaya L), Daun Sirsak (Annona mengenali foto bentuk daun dari tanaman tersebut. Dengan metode tersebut sehingga bisa dilakukan langkah- langkah pengenalan pola daun dengan mengidentifikasi Ciri Struktural daun semacam bentuk serta tekstur suatu daun. Tata cara untuk menerapkan pemrosesan terhadap citra masukan dengan pemanfaatan metode pengolahan citra Digital dicoba untuk menganalisa ciri Struktural daun [4].

Perkembangan teknlogi untuk Metode Pengolahan Citra Muricata L), dan Daun Sukun (Artocarpus).

\subsection{Morfologi Daun}

Daun merupakan alat Hara yang hanya terletak pada batang dan tidak pernah terdapat pada bagian lain. Daun dibagi menjadi Daun tunggal dan Daun Majemuk, pada Daun Majemuk terdapat sejumlah anak daun yang melekat pada tangkai daun atau perpanjangannya pada sumbu (Rachis) yang sama[6]. Bentuk - bentuk Daun dapat dilihat pada gambar 1. a) Pedang/Belati, b) Jarum, sangat jauh berkembang hingga saat ini. Berbagai Metode dikembangkan untuk membantu setiap kegiatan k) Lingkaran, 1) Ginjal, m) Jantung Terbalik, n) Jantung, manusia, baik sebagai pengolahan citra, analisis citra o) Belah Ketupat, p) Berbagi Menyirip, r) Tombak, s) maupun pengguna citra untuk tujuan dan keperluan. Anak Panah, dan t) Segitiga dapat dilihat pada gambar Seringkali citra yang digunakan tidaka dalam kondisi dibawah ini.

yang ideal untuk di kaji dikarenakan banyaknya gangguan, dapat berupa banyangan, foto atau gambar kabur, kurang jelasnya kenmpakan obyek sehingga dapat menimbulkan masalah dan mempengaruhi hasil interpelasi serta akan mempengaruhi analisa dan perencaan yang akan dilakukan, maka di perlukan berbagai teknik pengolahan citra untuk memperoleh citra yang ideal[5]

Pada penelitian serupa telah di lakukan identifikasi Citra Daun pada Tanaman Jeruk menggunakan Metode Local Binarry Patteren Histogram dengan 7 jumlah data uji, Proses identifikasi citra daun dilakukan denga mengidentifikasi Citra masukan untuk menganalisa karakteristik dari structural dau jeruk menggunakan Ekstraksi bentuk dan Ektraksi Tekstur[3].

Permasalahan yang terjadi saat ini ditengah masyarakat khususnya Masyarakat tingkat perkotaan ialah K-Nearest Neighbor adalah sebuah metode untuk kurangnya pengetahuan akan keberadaan tumbuhan - melakukan Klasifikasi terhadap objek berdasarkan data tumbuhan herbal yang sangat melimpah yang dapat pembelajaran yang jaraknya paling dekat dengan objek dimanfaatkan sebagai obat alternative atau pengobatan tersebut. Data pembelajaran di proyeksikan keruang alami. Untuk itu penulis mencoba melakukan penelitian berdimensi banyak, dimana masing masing dimensi dengan menguji 5 Jenis daun Herbal Sulawesi Tenggara merepresentasikan fitur dari data[7].

yang dapat di gunakan sebagai pengobatan Alternativ.

Sehingga dari kelima jenis daun herbal tersebut tidak diragukan lagi.
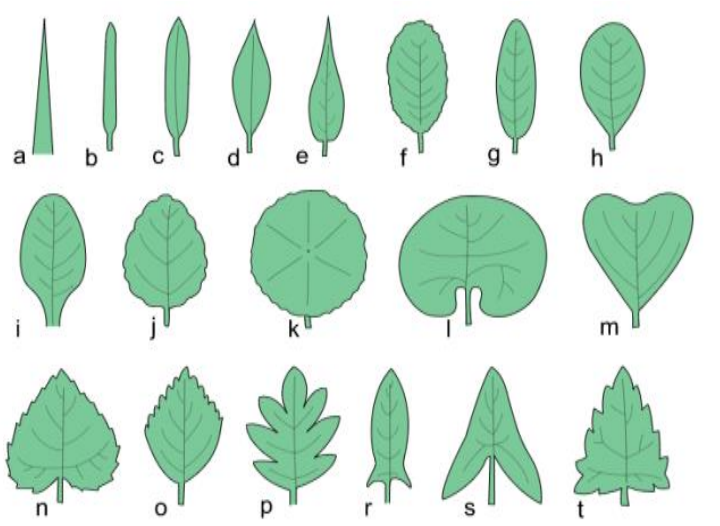

Gambar 1. Bentuk Daun
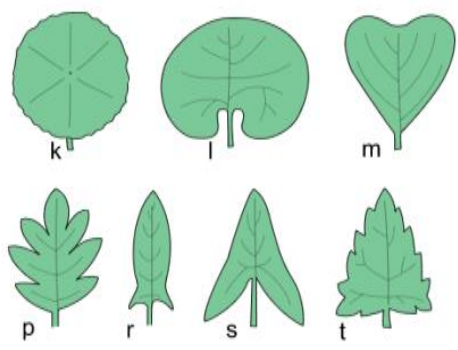

Ruang dimensi dibagi menjadi bagian bagian berdasarkan klasifikasi data pembelajaran. Nilai $k$ yang terbaik untuk Algoritma ini tergantung pada data. Secara

Pada penelitian ini penulis menggunakan Metode K- umum nilai $k$ yang tinggi akan mengurangi efek noise Nearest Neighbor $(\mathrm{KNN})$ dan Lokal Binari Patteren pada klasifikasi, akan tetapi membuat batasan antara 
setiap klasifikasi menjadi lebih kabur. Nilai $k$ yang 2.3.1 Cara Kerja Local Binary Pattern bagus dapat di pilih dengan optimasi parameter, misalnya dengan menggunakan Cross-validation. Kasus khusus dimana Klasifikasi di Prediksian berdasarkan data pembelajaran yang paling dekat (dengan kata Lain, $k=1$ ) yang biasanya disebut nearest neighbor [7].

\subsection{1 cara kerja metode K-Nearest Neighbor}

K-Nearest Neighbors melakukan klasifikasi dengan proyeksi data pembelajaran pada ruang berdimensi banyak. Ruang ini dibagi menjadi bagian-bagian yang merepresentasikan kriteria data pembelajaran. Setiap data pembelajaran direpresentasikan menjadi titik-titik c pada ruang dimensi banyak. Data baru yang diklasifikasi selanjutnya diproyeksikan pada ruang dimensi banyak yang telah memuat titik-titik c data pembelajaran. Proses klasifikasi dilakukan dengan mencari titik c terdekat dari c-baru (nearest neighbor). Teknik pencarian tetangga terdekat yang umum dilakukan dengan menggunakan formula jarak euclidean. Jarak Euclidean adalah formula untuk mencari jarak 2 titik dalam ruang dua dimensi. Berikut adalah formula Euclidean Distance yang digunakan pada algoritma KNN[8].

$$
d=\sqrt{\left(x_{2}-x_{1}\right)^{2}+\left(y_{2}-y_{1}\right)^{2}}
$$

Salah satu interpretasi dari metode LBP adalah nilai kecil dari ketetanggaan $3 \times 3$ yang tidak dapat mendeteksi karakteristik dominan dengan struktur skala besar. Untuk menghadapi tekstur skala yang berbeda, operator kemudian di abstraksi untuk menggunakan lingkungan dengan ukuran yang berbeda. Sebuah ketetanggaan local diartikan sebagai satu set titik sampel merata pada lingkaran, yang berpusat pada pixel yang akan di beri label, dan titik pengambilan sampel yang tidak termasuk dalam pixel ditambahkan menggunakan penambahan bilinear, sehingga dimungkinkan pada setiap radius dan sejulah titik sampel pada ketetanggan. Mengingat pixel

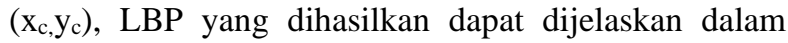
bentuk persamaan sebagai berikut[11]:

$$
L B P_{P, R}\left(x_{c}, y_{c}\right) \sum_{p=0}^{p-1} s\left(i_{p}-i_{c}\right) 2^{p}
$$

Dimana $i_{p}$ dan $i_{c}$ merupakan masing masing nilai dari nilai gray- level dari pusat pixel dan $P$ sekitarnya piksel di lingkungan lingkaran dengan $\mathrm{R}$ radius, dan $\mathrm{s}(\mathrm{x})$ [11].

\subsection{Confusion Matrix}

Confusion Matrix adalah suatu Metode yang dapat di

Pada penggunaan metode $\mathrm{KNN}$, hal yang pertama harus ditentukan banyaknya $k$ tetangga terdekat yang digunakan untuk melakukan klasifikasi data baru. Banyaknya $k$, paling baik merupakan angka ganjil, misalnya $k=1,2,3$, dan seterusnya. Penentuan nilai $k$ diperlu diperhatikan berdasarkan banyaknya data yang ada serta ukuran dimensi yang dibentuk oleh data. Semakin banyak data yang ada, angka k yang dipilih sebaiknya semakin rendah. Namun, semakin besar ukuran dimensi data, angka $\mathrm{k}$ yang dipilih sebaiknya semakin tinggi[8].

\subsection{Local Binary Pattern}

Local Binary Pattern merupakan salah satu metode untuk melakukan Ekstraksi ciri dan tekstur pada suatu data citra Grayscale, yang dapat di pakai dalam pengelompokan data dan model klasifikasi[9]. LBP termasuk kedalam salah satu ciri spasial yang meliputi tekstur. Operator dasar LBP berukuran $3 \times 3$ menggunakan 8 piksel ketetanggaan $i_{n}$ dari sebuah piksel tengah $i_{c}$. piksel ketetanggan ke- $n$ tersebut dithreshold menggunakan nilai keabuan dari piksel tengah dan fungsi thresholding $s(x)$. kode binary hasil operator LBP piksel ketetanggaan akan digunakan untuk merepresentasikan fitur dari piksel tengah $i_{c}$ [10].didalam Algoritma Local Binary Pattern, terdapat fitur Histogrsm yang dapat digunakan untuk mengolah data dari piksel yang memiliki nilai ketetanggan nilai ke$n$ dengan menggunakan nilai keabuan (grayscale) dimana $p$ adalah jumlah piksel tetangga dan $r$ adalah radius[9].

gunakan untuk perhitungan Akurasi pada Konsep Data

Mining. Confusion Matrix digambarkan dengan table yang menyatakan jumlah data Uji yang benar di klasifikasikan dan julah data uji yang salah diklsifikasikan. Table confusion Matrix dapat dilihat pada tabe 1 di bawah ini[12].

Table 1. Tabel Confusion matrix

\begin{tabular}{ccc}
\hline Correct & \multicolumn{2}{c}{ Classified } \\
Classification & Predicted “+” & Predicted “_“" \\
\hline Actual “+” & True Positives & False Negative \\
Actual "“_" & False Positives & True Negative \\
\hline
\end{tabular}

Berdasarkan tabel Confusion Matrix diatas dapat dijelaskan: True Positive (TP) adalah jumlah record data Positif yang di klasifikasikan sebagai nilai positif, False Positives (FP) adalah jumlah data record data negative yang di klasifikasikan sebagai nilai positif, False Negatives (FN) adalah jumlah record data positif yang di klasifikasikan sebagai nilai positif, sedangkan True Negatives (TN) adalah jumlah record data negative yang di klasifikasikan sebagai nilai negative.

Nilai yang di hasilkan melalui melalui metode Confusion Matrix adalah berupa evaluasi yang pertama Accuracy, Presentase jumlah record data yang klasifikasikan (prediksi) secara benar oleh Algoritma. Yang kedua Misclassification Rate, presentase jumlah record data yang di klasifikasikan (prediksi) salah oleh Algoritma[12].

\section{Hasil dan Pembahasan}

Untuk pengenalan Daun Herbal dalam penelitian ini menggunakan 100 Dataset yang terdiri dari Daun Balakacida 20, Daun Pepaya 20, Daun Sirih 20, dan 
Sirsak 20 dan Daun Sukun 20. Adapun dalam pengujičn menggunakan total 40 gambar daun yang terdiri dari Daun Balakacida 8, daun Pepaya 8, daun Sirih 8 daun Sirsak 8 dan Daun Sukun 8. Setiap gambar dataset maupun datauji telah di Resize (ubah ukuran) Pix $\in$ l, menjadi 300x300. Berikut adalah tabel Jenis Daun Herbal Sulawesi Tenggara yang digunakan dalam Penelitian ini.

Tabel 2. Jenis Daun Herbal

\begin{tabular}{cc}
\hline Jenis Daun Herbal & Ket \\
Balakacida \\
(Chromolaena \\
Odorata $)$ \\
Siri \\
(Piper Betle) \\
Pepaya \\
(Carica Papaya L)
\end{tabular}

\subsection{Flowchart Sistem}

Dalam mendukung kinerja system yang akan di buat oleh peneliti dalam pengklasifikasian Tumbuhan Herbal maka penulis telah membuat Plwochart system sebagai acuan dalam membuat system yang akan digunakan. Berikut ( Gambar 2, 3) adalah gambaran system yang akan dibuat.

\subsection{Pengenalan Daun Menggunakan Metode KNN}

Implementasi Antarmuka dilakukan dengan setiap halaman Aplikasi yang di buat dan Pengkodeannya dalam bentuk File Program. Berikut (Gambar 4, 5) adalah Screnshot Implementasi Antarmuka menggunakan Metode K-Nearest Neighbor (KNN).

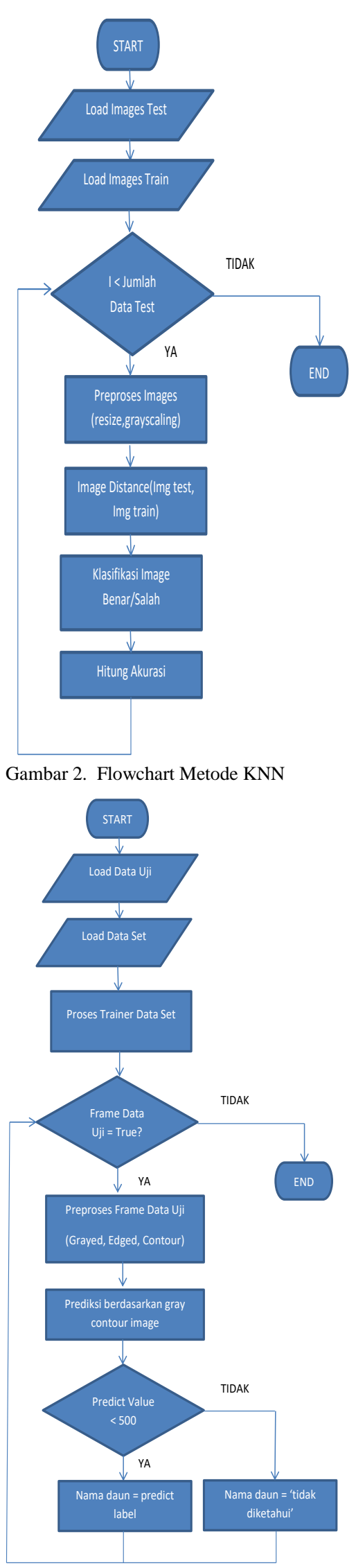

Gambar 3. Flowchart Metode LBPH 


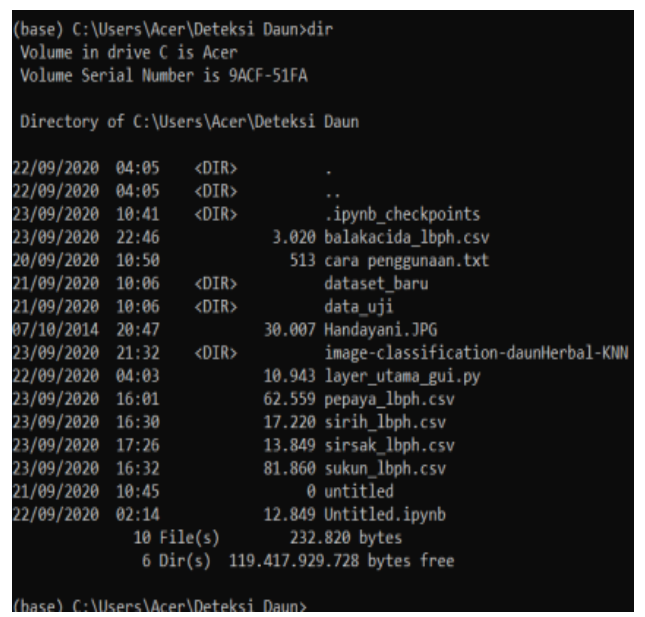

Gambar 4. Tampilan Awal Interface Metode KNN

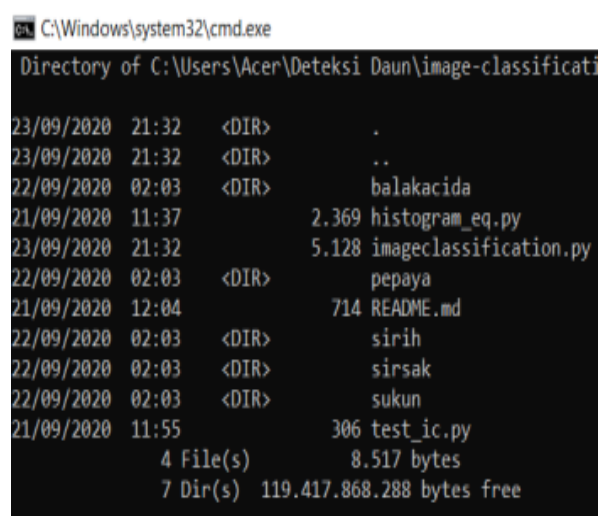

Gambar 5. Tahap Pengambilan Data

pada gambar 6 di atas merupakan tahapan pengujian data uji yang dlakukan oleh system, pada tahapan ini system akan melakukan klasifikasi daun yang sedang du uji, apakah data tersebut terdeteksi benar (Positive) oleh system ataukah data tersebut terdeteksi sebagai data negative oleh system, apabila data tersebut terdeksi benar oleh system makan hasilnya akan di tampilkan ssesuai dengan jenis data (daun) yang sedang di uji namun apa bila hasilnya terdeteksi salah (negative) makan hasilnya bisa berbeda.

\subsection{Pengenalan Daun Menggunakan Metode LBPH}

Implementasi Antarmuka dilakukan dengan setiap halaman Aplikasi yang di buat dan Pengkodeannya dalam bentuk File Program. Berikut adalah Screnshot Implementasi Antarmuka menggunakan Metode Local Binarry Pattern Histogram (LBPH).

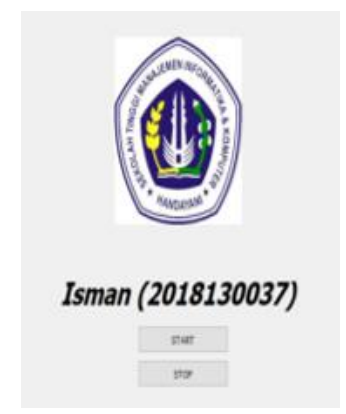

Gambar 7. Tahap Awal Masuk Pengujian Daun Herba

Gambar 7 merupakan tampilan awal system yang telah di buat dengan menggunakan metode Local Binarry Pada tahap ini merupakan tampilan sistem, dimana Pattren Histogram, dimana pada tahapan ini merupakan pengguna dalam hal ini peneliti akan melakukan proses tahapan awal ketika user akan melakukan pengujia data pengambilan data uii yang telah kita olah sebelumnya test. Ketika user melakukan tahapan selanjutnya maka dan telah kira simpan dalam sebuah folder tertentu. kita akan melakukan loading data uji atau tahapan Setelah data uji telah berhasil di ambil maka selanjutnya pengambilan data uji yang telah kita proses dan telah akan dilakukan tahapan pengujian data (pengujian dauh kita traning seblemunya, sehingga akan tampak seperti herbal) sebagaimana telah kami tampilkan pada gambar pada gambar 8 . 6.
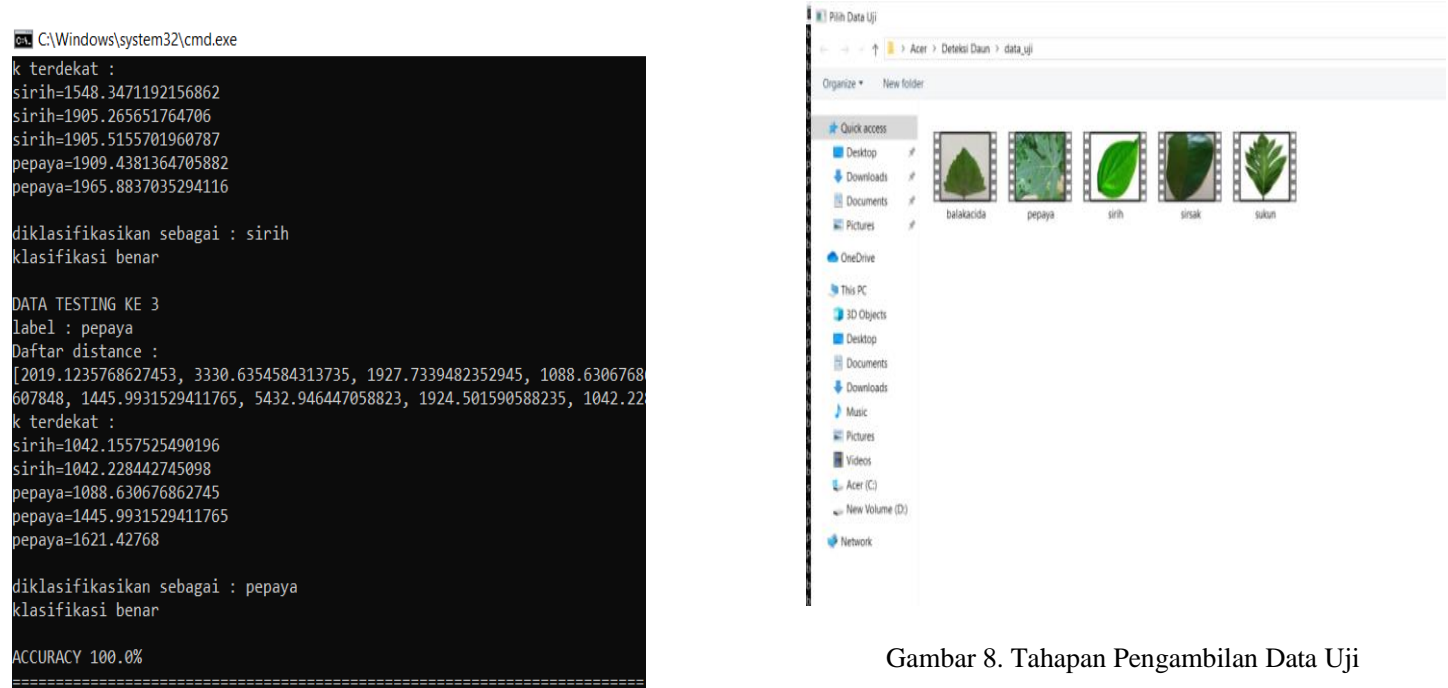

Gambar 8. Tahapan Pengambilan Data Uji

DOI: https://doi.org/10.29207/resti.v5i3.3006

Creative Commons Attribution 4.0 International License (CC BY 4.0) 


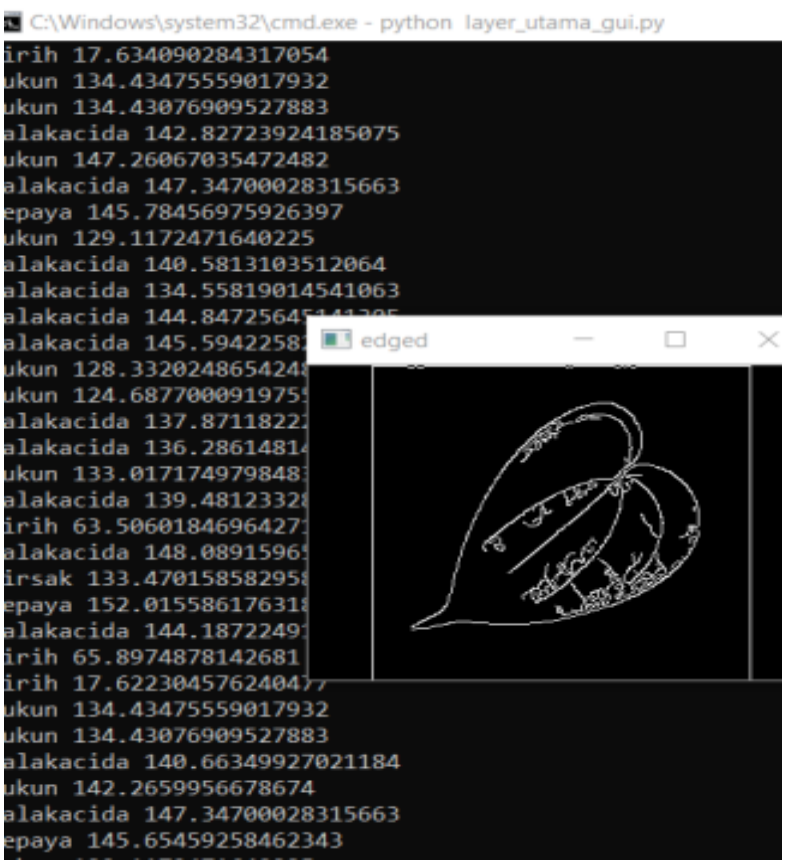

Gambar 9. Contoh Proses Pengujian Daun Herbal

Pada gambar 9 diatas merupakan proses pengujian daun herbal balakacida yang dilakukan oleh system yang telah kita buat, dan tampak di samping kiri merupaka angka angka hasil pengujian system yang dapat memberikan informasi apakah daun herbal tersebut terdeteksi positif(benar) oleh system atau negative. Jika ada data yang terdeteksi salah makan system akan membaca data tersebut bukan sebagai dau herbal balakacida.

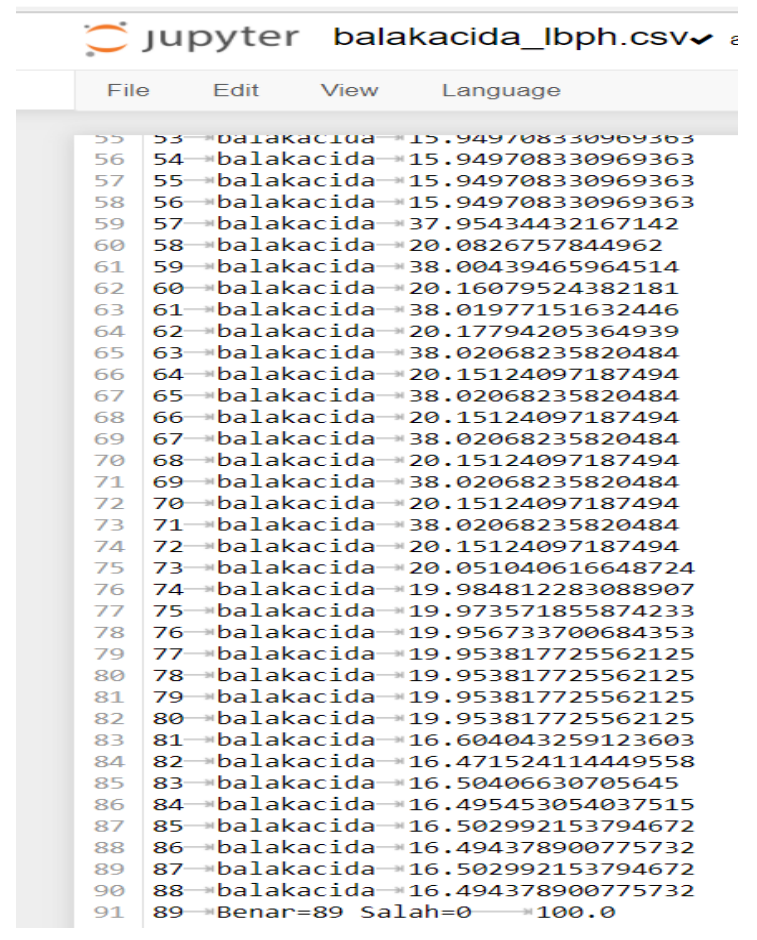

Gambar 10. Hasil Pengujian Daun Herbal
Pada gambar 10 merupakan hasil pengujian daun Herbal Balakacida yang dilakukan oleh system dengan menggunakan Program Phyton, dan system mampu melakukan pembacaan gambar dengan benar sehingga hasil yang di tampilkan adalah 100 persen daun Balakacida terdektesi positif atau benar oleh system.

\subsection{Pembahasan Pengenalan Daun Menggunakan Metode K-Nearest Neighbor (KNN)}

Dari hasil perhitungan Confusion Matrix yang dilakukan menggunakan metode K-Nearest Neighbor untuk perbandingan kelima daun Herbal yang ada di Sulawesi Tenggara maka dihasilkan nilai sebagaimana di tampilkan pada tabel berikut:

\begin{tabular}{cccccc}
\multicolumn{5}{c}{ Tabel. 3 Confusion Matrix Daun Herbal } \\
\cline { 2 - 6 } & ACTUAL CLASS \\
\hline Balakacida & Balakacida & Pepaya & Sirih & Sirsak & Sukun \\
Pepaya & 8 & 0 & 0 & 0 & 0 \\
Sirih & 0 & 7 & 1 & 0 & 0 \\
Sirsak & 0 & 0 & 8 & 0 & 0 \\
Sukun & 0 & 0 & 0 & 8 & 0 \\
Not & 0 & 0 & 0 & 0 & 8 \\
Reconized & 0 & 1 & 0 & 0 & 0 \\
\hline
\end{tabular}

$$
\begin{aligned}
\text { Akurasi } & =\frac{8+7+8+8+8}{40} \times 100 \% \\
& =0,975 \times 100 \% \\
& =97,5 \%
\end{aligned}
$$

Hasil dari perhitungan Confusion Matrix pada kolom Predic Class dan Atual Class bahwa jumlah data yang di prediksi dibandingkan dengan Actual Clas (jumlah data yang terdeteksi benar oleh system) dengan K-Nearest Neighbor pada tabel 3 daun herbal Balakacida 8 data uji positif yang terklarifikasi dengan benar dan 0 data positif namun terklasirifikasi salah oleh system. Pada pengujian daun herbal Pepaya nilai terdeteksi 7 data uji Positif yang terklarifikasi dengan benar oleh system dan 1 data uji yang terdeteksi salah oleh system sehingga dapat mempengaruhi nilai akurasi. Sedangkan untuk pengujian pada daun herbal sirih ditemukan hasil 8 daun yang terdeteksi benar oleh system dan 0 yang terklarifikasi salah. Pada pengujian daun herbal sirsak ditemukan 8 data uji terdeteksi benar oleh system dan tidak ditemukan data uji yang dideteksi salah oleh system. Untuk pengujian daun herbal terakhir yakni daun hebrla Sukun system menkonfirmasi 7 data uji terdeteksi benar dan 1 data uji yang terkonfirmasi salah oleh system. Dari 80 data uji kelima daun herbal tersebut, didapat total daun balakacida yang terdeteksi 8 dinyatakan benar, 7 daun Pepaya dinyatakan Positif, 8 Daun terdeteksi benar untuk daun herbal Sirih,8 daun terdeteksi benar sebagai daun sisrsak dan 7 Daun sukun terdeteksi benar oleh system. Dari hasil pengujian ini didapat Nilai Akurasi dengan menggunakan Metode KNearest Neighbor di dapat Nilai Akurasi sebesar $97 \%$.

DOI: https://doi.org/10.29207/resti.v5i3.3006

Creative Commons Attribution 4.0 International License (CC BY 4.0) 
3.5 Pembahasan Pengenalan Daun Menggunakan Local Binary Pattern Histogram (a). Pada pengujian Metode Local Binarry Pattren Histogram

Dari hasil Perhitungan Confusion Matrix yang dilakukan menggunakan metode Local Binary Pattern Histogram untuk perbandingan kelima Daun Herbal yang ada di Sulawesi Tenggara maka dihasilkan nilai sebagai berikut.

Tabel 4. Confusion Matrix Daun Herbal

\begin{tabular}{c|ccccc|}
\cline { 2 - 6 } & \multicolumn{5}{c|}{ ACTUAL CLASS } \\
\hline & Balakacida & Pepaya & Sirih & Sirsak & Sukun \\
\hline Balakacida & 100 & 0 & 0 & 0 & 0 \\
Pepaya & 32 & 480 & 44 & 30 & 20 \\
Sirih & 3 & 4 & 280 & 8 & 2 \\
Sirsak & 0 & 10 & 5 & 287 & 0 \\
Sukun & 0 & 40 & 10 & 13 & 315 \\
Not & 0 & 126 & 17 & 15 & 63 \\
Reconized & & & & & \\
\hline
\end{tabular}

$$
\begin{aligned}
\text { Akurasi } & =\frac{100+480+280+287+315}{1543} \times 100 \% \\
& =0,94 X 100 \% \\
& =94 \%
\end{aligned}
$$

Daun Herbal Balakacida (Chromolaena Odarata) didapatkan Nilai Akurasi sebesar 100\%, (b). Pada Pengujian Daun Herbal Sirih (Piper Betle) didapatkan Nilai Akurasi sebesar 79\%, (c). Pada Pengujian Daun Herbal Sirsak (Annona Muricata L) diperoleh Nilai Akurasi sebesar 94\%, (d). Pada Pengujian Daun Herba Pepaya (Carica Papaya L) didapatkan Nilai Akurasi sebesar $95 \%$, dan (e). Sedangkan pada untuk Daun Herbal Sukun (Artocarpus) didapatkan Nilai Akurasi Sebesar $83 \%$.

Dari Pengujian ke Lima Jenis Daun Herbal yang di jadikan sampel dalam Penelitian ini, maka di dapatkan Hasil Akurasi pada Pengujian menggunakan Metode $K$ -

15 Nearest Neighbor (KNN) didapatkan Nilai Akurasi 3 Sebesar 97,5\%. sedangkan pada Pengujian menggunakan Metode Local Binary Pattern Histogram (LBPH) diapatkn Nilai Akurasi sebesar 94\%. Hal ini menunjukkan bahwa Kinerja Metode K-Nearest Neighbor masih lebih unggul dibandingkan Metode Local Binary Pattern Histogram dalam Penelitian ini.

Dari Hasil Perhitungan Confusion Matriks Pada Tabel 9 Daftar Rujukan

yang dilakukan dengan Menggunakan Metode Local Binary Pattern Histogram (LBPH) pada pengujian Daun Herbal yang telah ditentukan makan dihasilkan Nilai untuk Daun Herbal Balakacida 100 data Uji terdeteksi benar oleh system dan tidak terdapat data yang terdeteksi salah, untuk daun Hebarl Pepaya didapatkan hasil 480 data yang terkonfirmasi benar oleh Sistem dan terdapat 126 data yang terdeteksi salah, sedangkan pada daun sirih terdapat 280 data yang terdeteksi benar oleh system dana ditemukan 17 data yang terkonfirmasi salah oleh system, pada daun Sirsak didapat 287 data yang terdeteksi benar oleh system dan 15 data yang terdeteksi salah, sedangkan untuk daun herbal Sukun didapatkan 315 data yang terdeteksi benar dan 63 data terdetksi salah oleh system.

\section{Kesimpulan}

Indrawati, Y. Sabilu, and P. F. Zainal, "Keanekaragamaan dan pemanfaatan tumbuhan obat tradisional pada masyarakat di Kelurahan Lipu Kecamatan Betoambari Kota Baubau Provinsi Sulawesi Tenggara," Biowallacea, vol. 2, no. 1, pp. 204-210, 2015.

[2] "seminar-herbal-bagi-akademisi-kedokteran-upaya-menggalipotensi-tanaman @ yogyakarta.kompas.com,” [Online]. Available:

https://yogyakarta.kompas.com/read/2019/07/29/17395341/se minar-herbal-bagi-akademisi-kedokteran-upaya-menggalipotensi-tanaman.

[3] F. S. Ni'mah, T. Sutojo, and D. R. I. M. Setiadi, "Identifikasi Tumbuhan Obat Herbal Berdasarkan Citra Daun Menggunakan Algoritma Gray Level Co-occurence Matrix dan K-Nearest Neighbor," J. Teknol. dan Sist. Komput., vol. 6, no. 2, pp. 5156, 2018, doi: 10.14710/jtsiskom.6.2.2018.51-56.

[4] F. Liantoni, "Klasifikasi Daun Dengan Perbaikan Fitur Citra Menggunakan Metode K-Nearest Neighbor," J. Ultim., vol. 7, no. 2, pp. 98-104, 2016, doi: 10.31937/ti.v7i2.356.

[5] R. Rahmadewi, E. Purwanti, and V. Efelina, "Identifikasi Jenis Tumbuhan Menggunakan Citra Daun Berbasis Jaringan Saraf Tiruan (Artificial Neural Networks)," J. Media Elektro, vol. VII, no. 2, pp. 38-43, 2018, doi: 10.35508/jme.v0i0.427.

Dari hasil uji coba klasifikasi citra daun herbal menggunakan Metode K-Nearest Neighbour dan Local Binary Pattern Histogram didapatkan Akurasi sebagai berikut.

K-Nearest Neighbour (a). Pada Pengujian Daun Herbal Balakacida (Chromolaena Odarata) didapatkan Nilai Akurasi Sebesar 100\%, (b). Pada Pengujian Daun Herbal Sirih (Piper Betle) di dapatkan Nilai Akurasi sebesar 90\%, (c). Pada pengujian Daun Herbal Sirsak (Annona Muricata L) didapatkan Akurasi sebesar 100\%, (d). Pada Pengujian Daun Herbal Pepaya (Carica Papaya L) didapatkan Nilai Akurasi sebesar 100\%, dan (e). Sedangkan untuk Pengujian pada Daun Herbal Sukun (Artocarpus) di Dapatkan Nilai Akurasi sebesar "Morfologidaun@ @id.wikipedia.org."[Online]. Available https://id.wikipedia.org/wiki/Morfologi_daun.

[7] M. Astuti, F. D., \& Guntara, "Analisis Performa Algoritma KNN Dan C4 . 5 Pada Klasifikasi Data Penduduk Miskin," Jurti, vol. 2, no. 2, pp. 135-142, 2018.

[8] "cc4c88fca4aa9bf877b621b40dc327f68aee4f12 @ www.advernesia.com." [Online]. Available: https://www.advernesia.com/blog/data-science/pengertian-dancara-kerja-algoritma-k-nearest-neighbours-knn/.

[9] R. Sistem, P. N. Andono, and E. H. Rachmawanto, "JURNAL RESTI Evaluasi Ekstraksi Fitur GLCM dan LBP Menggunakan Multikernel SVM," vol. 1, no. 10, pp. 1-9, 2021.

[10] A. Novitasari, E. P. Purwandari, and F. F. Coastera, "Identifikasi Citra Daun Tanaman Jeruk Dengan Local Binary Pattern Dan Moment Invariant," J. Inform. dan Komput., vol. 3, no. 2, pp. 76-83, 2018.

DOI: https://doi.org/10.29207/resti.v5i3.3006

Creative Commons Attribution 4.0 International License (CC BY 4.0) 
[11] F. Y. Rahman, "Pendeteksian Citra Wajah Manusia Dari Berbagai Posisi Menggunakan Local Binary Pattern (Lbp)," Technol. J. Ilm., vol. 8, no. 4, p. 257, 2017, doi: 10.31602/tji.v8i4.1126.

[12] M. F. Rahman, D. Alamsah, M. I. Darmawidjadja, and I. Nurma, "Klasifikasi Untuk Diagnosa Diabetes Menggunakan Metode Bayesian Regularization Neural Network (RBNN), $J$. Inform., vol. 11, no. 1, p. 36, 2017, doi: 10.26555/jifo.v11i1.a5452. 